\title{
Clinical and histopathological analysis of the patients undergoing appendectomy
}

\author{
Kamal Koirala ${ }^{1}$, Shiva R KC ${ }^{2}$, Ganesh Simkhada ${ }^{1}$, Rupesh Mukhia ${ }^{1}$, \\ Nisheem Pokharel $^{1}$, Geetika KC ${ }^{2}$ \\ ${ }^{I}$ Department of General Surgery, KIST Medical College and Teaching Hospital, Lalitpur, Nepal \\ ${ }^{2}$ Department of Pathology, KIST Medical College and Teaching Hospital, Lalitpur, Nepal
}

\section{Keywords:}

Appendicitis; Appendicular lump; Modified Alvarado score;

\begin{abstract}
Background: Acute appendicitis is one of the most common surgical emergencies, but the diagnosis is difficult even with the sophisticated diagnostic tools. The aim of this study is to analyze the clinical and histopathological features of acute appendicitis and to see how reliable the clinical scoring system modified Alvarado score in our setup.
\end{abstract}

Materials and Methods: This was a retrospective observational study of patients who underwent appendectomy at KIST Medical College and Teaching Hospital during two years. The clinical characteristics of the patients in terms of modified Alvarado scoring were outlined. The diagnosis of acute appendicitis was confirmed by histopathological examination. The data were tabulated in MS-Excel and statistically analyzed using SPSS statistics software, version 21.

Results: Among 118 patients, who underwent appendectomy, 69 were male and 49 were female with male to female ratio of $1.41: 1$ and mean age of $27.46 \pm 12.724$ years. The clinical diagnosis of acute appendicitis was more likely (MAS 7-9) in 56 patients, less likely (4-6) in 44 patients and unlikely (MAS 1-3) in 18 patients. The highest incidence of acute appendicitis was observed in 19-40 years and the lowest incidence in 61 years or above. After histopathological examination, 52 patients out of 56 in the more likely group had acute appendicitis and 4 patients had non-inflamed appendices. 7 patients out of 62 in the less likely and unlikely groups had acute appendicitis and 55 patients had non-inflamed appendices. The overall negative appendectomy rate was 9.32 percent.

Conclusion: Our clinical practice of using modified Alvarado score in the diagnosis of acute appendicitis is effective, easy and non-invasive.

\section{Correspondence:}

Dr. Kamal Koirala, MS, PhD

Associate Professor, Department of Surgery,

KIST Medical College and Teaching Hospital, Lalitpur, Nepal

ORCID ID: 0000-0002-8390-8297

Email:drkkoirala@gmail.com

Received : July $20^{\text {th }} 2018$; Accepted : August 13 ${ }^{\text {th }} 2018$; Published : September $1^{\text {st }} 2018$

Citation: Koirala K, KC Shiva R, Simkhada G, Mukhia R, Pokharel N, KC Geetika. Clinical and histopathological analysis of the patients undergoing appendectomy. J Pathol Nep 2018;8:1337-40 DOI: $10.3126 /$ jpn.v8i2.20862

Copyright: This is an open-access article distributed under the terms of the Creative Commons Attribution 4.0 International License, which permits unrestricted use, distribution, and reproduction in any medium, provided the original author and source are credited.

\section{INTRODUCTION}

Acute appendicitis is one of the most common diseases encountered in emergency. This disease needs emergent surgical intervention. ${ }^{1}$ The diagnosis is made pre-operatively with certain scoring systems and the decision of emergency appendectomy is taken on the basis of these scores. ${ }^{2}$ Though the sophisticated investigatory investigations are being evolving, they are not able to confirm the diagnosis all the time. In our setup, due to financial constraint, most of our patients cannot afford expensive investigations so we depend only on the scoring systems. We use modified Alvarado scoring (MAS) system to make the diagnosis of 
Table 1: Features of Modified Alvarado Score

\begin{tabular}{l|c}
\hline \multicolumn{1}{c}{ Examination/Test } & Score \\
\hline $\begin{array}{l}\text { Migratory pain from epigastric region to right } \\
\text { lower quadrant }\end{array}$ & 1 \\
\hline Anorexia & 1 \\
\hline Nausea or vomiting & 1 \\
\hline Tenderness in the right lower quadrant & 2 \\
\hline Rebound tenderness over McBurney's point & 1 \\
\hline Fever & 1 \\
\hline Leucocytosis & 2 \\
\hline Total Modified Alvarado Score (MAS) & 9 \\
\hline
\end{tabular}

acute appendicitis. The parameters of this scoring system can be remembered with the pneumonic MANTREL (migrating pain, anorexia, nausea or vomiting, tenderness, rebound tenderness, elevated temperature and leucocytosis). The modified Alvarado scoring system has been shown to be easy, simple and cheap diagnostic tool for supporting the diagnosis of acute appendicitis. ${ }^{3}$ In this study, we wanted to see how reliable was the clinical scoring system i.e.modified Alvarado scoring and also its correlation with the different types of histopathological findings.

\section{MATERIALS AND METHODS}

This was a retrospective observational study conducted at KIST Medical College and Teaching Hospital. A capital from the institutional review committee was obtained. The medical records of the patients who underwent appendectomy either by open or laparoscopic method during two years (july1, 2016 to jun30, 2018) were searched. The Patients who had no complete information in the medical records were excluded from the study. 118 patients fulfilling the inclusion criteria were included in the study. The clinical characteristics of the patients in terms of modified Alvarado Score were outlined. The modified Alvarado Scoring system included three symptoms (migration of pain to the right iliac fossa, anorexia and nausea or vomiting), three physical signs (tenderness, rebound tenderness and elevation of temperature) and one laboratory finding (leukocytosis). (Table 1) The strength of the parameters were different as shown in Table 1. Final score was obtained after adding all parameters. The diagnosis of acute appendicitis was confirmed by histopathological examination. The different histopathological findings of the appendix were obtained from pathological department.

\section{Statistical analysis}

All the observed data of the clinical characteristics of the patients and the histopathological findings of appendix were tabulated in MS-Excel and statistically analyzed using SPSS statistics software, version 21.

\section{RESULTS}

In our study of 118 (69 males and 49 females) patients with M:F ratio of 1.41:1, the highest number of patients (66.96\%) were observed in the age group of 19 to 40 and the least number of patients $(3.39 \%)$ were observed in the age group of 61 years and above (table 2,3). The mean age of patients in our study was $27.46 \pm 12.724$ years (male $26.41 \pm 12.651$ years and female $28.94 \pm 12.809$ years).

We divided the modified Alvarado scores into three categories as unlikely (MAS 1-3), less likely (MAS 4-6) and more likely (MAS 7-9) groups. The modified Alvarado score of $<4$ was observed in 18 patients, $4-6$ in 44 patients, 7-9 in 56 patients (table 4). In our study, 56 patients (clinical positive) were in the more likely appendicitis (MAS 7-9) group, 62 patients (clinical negative) were in less likely or unlikely groups (MAS 6 or less). After histopathological examination, 52 patients (true positive) out of 56 had acute appendicitis and 4 patients (false positive) had noninflammed appendices. Seven patients (true negative) out of 62 had acute appendicitis and 55 patients (false negative) had non-inflamed appendices. (table 5)

\section{DISCUSSION}

Acute appendicitis is one of the most common surgical emergencies. The highest incidence is in the age group of 15-24 years. ${ }^{4}$ There is an approximately $8 \%$ estimated life time prevalence of acute appendicitis with peak incidence in the age group 10-30 years. ${ }^{5}$ In our study, the highest incidence of acute appendicitis was observed in 19-40 years and the lowest incidence in 61 years or above (table 2). In our study of 118 (69 males and 49 females) patients (table 3 ), male to female ratio was $1.41: 1$, which was higher in contrast to other studies. ${ }^{6,7}$

Table 2: Study population characteristics of patients who underwent appendectomy

\begin{tabular}{|c|c|c|c|c|c|c|c|}
\hline \multicolumn{8}{|c|}{ Histopathological Finding } \\
\hline Years & & $\begin{array}{c}\text { Acute } \\
\text { appendicitis }\end{array}$ & $\begin{array}{c}\text { Acute } \\
\text { appendicitis with } \\
\text { periappendicitis }\end{array}$ & $\begin{array}{c}\text { Acute } \\
\text { suppurative } \\
\text { appendicitis }\end{array}$ & $\begin{array}{l}\text { Gangrenous } \\
\text { appendicitis }\end{array}$ & $\begin{array}{l}\text { Submucosal } \\
\text { lymphoid } \\
\text { hyperplasia }\end{array}$ & Tota \\
\hline \multirow{4}{*}{$\begin{array}{l}\text { Age } \\
\text { Group }\end{array}$} & 18 or less & 10 & 10 & 1 & 4 & 2 & 27 \\
\hline & $19-40$ & 37 & 24 & 2 & 4 & 8 & 75 \\
\hline & $41-60$ & 3 & 6 & 1 & 2 & 0 & 12 \\
\hline & 61 or more & 2 & 0 & 0 & 1 & 1 & 4 \\
\hline Total & & 52 & 40 & 4 & 11 & 11 & 118 \\
\hline
\end{tabular}


Table 3: Sex-wise histological diagnosis of patient undergoing appendectomy

\begin{tabular}{|c|c|c|c|c|c|c|c|}
\hline \multicolumn{8}{|c|}{ Histopathological Finding } \\
\hline Years & & $\begin{array}{c}\text { Acute } \\
\text { appendicitis }\end{array}$ & $\begin{array}{c}\text { Acute } \\
\text { appendicitis with } \\
\text { periappendicitis }\end{array}$ & $\begin{array}{c}\text { Acute } \\
\text { suppurative } \\
\text { appendicitis }\end{array}$ & $\begin{array}{l}\text { Gangrenous } \\
\text { appendicitis }\end{array}$ & $\begin{array}{l}\text { Submucosal } \\
\text { lymphoid } \\
\text { hyperplasia }\end{array}$ & Total \\
\hline \multirow{2}{*}{ Sex } & Male & 31 & 24 & 3 & 8 & 3 & 69 \\
\hline & Female & 21 & 16 & 1 & 3 & 8 & 49 \\
\hline Total & & 52 & 40 & 4 & 11 & 11 & 118 \\
\hline
\end{tabular}

Table 4: Comparison between Modified Alvarado score and histopathological diagnosis

\begin{tabular}{|c|c|c|c|c|c|c|c|}
\hline \multirow{2}{*}{\multicolumn{2}{|c|}{$\begin{array}{l}\text { Modified Alvarado } \\
\text { scoring }\end{array}$}} & \multicolumn{5}{|c|}{ Histopathological Finding } & \multirow[b]{2}{*}{ Total } \\
\hline & & $\begin{array}{c}\text { Acute } \\
\text { appendicitis }\end{array}$ & $\begin{array}{c}\text { Acute } \\
\text { appendicitis with } \\
\text { periappendicitis }\end{array}$ & $\begin{array}{c}\text { Acute } \\
\text { suppurative } \\
\text { appendicitis }\end{array}$ & $\begin{array}{l}\text { Gangrenous } \\
\text { appendicitis }\end{array}$ & $\begin{array}{c}\text { Submucosal } \\
\text { lymphoid } \\
\text { hyperplasia }\end{array}$ & \\
\hline & $1-3$ & 10 & 4 & 0 & 2 & 2 & 18 \\
\hline & $4-6$ & 19 & 18 & 1 & 1 & 5 & 44 \\
\hline & $7-9$ & 23 & 18 & 3 & 8 & 4 & 56 \\
\hline Total & & 52 & 40 & 4 & 11 & 11 & 118 \\
\hline
\end{tabular}

If appendectomy is delayed, there are high chances of complications like appendicular perforation and sepsis with high mortality ${ }^{8}$ and in contrast with reduced diagnostic accuracy, rate of negative appendectomy increases which is generally reported to be approximately $(20-40 \%) .{ }^{9}$ The morbidity and mortality of omitting the surgery for acute appendicitis are sometimes far severe than performing a certain percentage of negative appendicectomy. Our rate of negative appendicectomy was $9.32 \%$, lower than the rate mentioned in the literature. ${ }^{9}$ This may be due to the involvement of more male patients in our study because diagnosing acute appendicitis in the female patients is more challenging. Females always have more negative appendectomy than males because of gynecological conditions mimicking appendicitis. ${ }^{6,7,10,11}$ Now sophisticated diagnostic modalities like CT scan, MRI etc. are also available and the diagnostic accuracy can be improved. But most of the people in our region cannot afford these costly modalities. At present, various scoring systems are available to improve diagnostic accuracy. Alvarado and modified Alvarado scores are most popular with reported sensitivity and specificity of both are 53 to $88 \%$ and 75 to $80 \%$, respectively., ${ }^{9,12}$ In our study, the sensitivity of the modified Alvarado scores was $48.60 \%$, specificity $63.64 \%$, positive predictive value $92.86 \%$, and negative predictive value $11.29 \%$ with diagnostic accuracyof $47.46 \%$.

Whenever we correlated the MAS with the histopathological examinations of the resected appendiceal specimen (table 4 ), we found that negative appendectomy rate was the lowest $(7.14 \%)$ in the more likely group. However, the negative appendectomy rates were more or less similar $(11.11 \%$ vs $11.36 \%)$ among the unlikely and less likely groups respectively. Thus the MAS can be used to diagnose acute appendicitis in the emergency setting.

As shown in the table 5, the intraoperative findings are not seen to be consistent with histopathological findings. Out of 78 cases diagnosed intraoperatively as acute appendicitis, 8 cases showed no appendiceal inflammation. Out of 12 cases of intraoperative gangrenous appendicitis, only 8 cases turned to be so after HPE. Out of 24 appendicular lump cases, 2 appendices were normal in HPE. So we should send all types of appendiceal specimen for histopathological examination to come to the final accurate diagnosis.

There were some limitations in our study. The sample size of this study was small to validate this scoring system and our study was conducted in a single private medical college within a certain period of time

Nowadays, other scoring systems are also available. RIPASA being one of such scoring system studied. RIPASA scoring system is shown to be superior to the modified Alvarado scoring in terms of sensitivity, specificity and negative appendectomy rate. ${ }^{4}$ However another recent study showed no advantages of RIPASA scoring system over the modified Alvarado score when applied to the patients presenting with suspected acute appendicitis. ${ }^{13}$ In a recently published study ${ }^{14}$, comparison among the seven scoring systems namely the Alvarado score (AS), modified Alvarado score (MAS), Fenyo-Lindberg score (FS), Lintula score (LS), Eskelinen score (ES), Teicher score (TS), and Christian score (CS) was done and concluded that FS, LS, and TS had a lower diagnostic sensitivity in women; and FS, ES, TS, and CS had a low sensitivity in patients with a duration of illness greater than 48 hours. Ohmann and Eskelinen scores were found superior to modified Alvarado score in another study. ${ }^{15}$

In future, we should involve a large number of patients in a prospective study to compare the diagnostic accuracy of multiple scoring systems in our setup. Multi centric data can be utilized. 


\begin{tabular}{|c|c|c|c|c|c|c|}
\hline \multirow[b]{2}{*}{ Operative findings } & \multicolumn{5}{|c|}{ Histopathological Finding } & \multirow[b]{2}{*}{ Total } \\
\hline & $\begin{array}{c}\text { Acute } \\
\text { appendicitis }\end{array}$ & $\begin{array}{c}\text { Acute } \\
\text { appendicitis with } \\
\text { periappendicitis }\end{array}$ & $\begin{array}{c}\text { Acute } \\
\text { suppurative } \\
\text { appendicitis }\end{array}$ & $\begin{array}{l}\text { Gangrenous } \\
\text { appendicitis }\end{array}$ & $\begin{array}{c}\text { Submucosal } \\
\text { lymphoid } \\
\text { hyperplasia }\end{array}$ & \\
\hline Inflammed appendix & 40 & 28 & 1 & 1 & 8 & 78 \\
\hline Appendicular lump & 12 & 8 & 2 & 0 & 2 & 24 \\
\hline $\begin{array}{l}\text { Gangrenous } \\
\text { appendix }\end{array}$ & 0 & 3 & 1 & 8 & 0 & 12 \\
\hline $\begin{array}{l}\text { Appendicular } \\
\text { abscess }\end{array}$ & 0 & 1 & 0 & 2 & 0 & 3 \\
\hline $\begin{array}{l}\text { Inflammed fallopian } \\
\text { tube }\end{array}$ & 0 & 0 & 0 & 0 & 1 & 1 \\
\hline Total $(n=25)$ & 52 & 40 & 4 & 11 & 11 & 118 \\
\hline
\end{tabular}

\section{CONCLUSION}

We conclude that our clinical diagnosis of acute appendicitis by using the modified Alvarado scoring system is effective, easy and non-invasive tool in our region where most of the patients cannot afford other sophisticated and costly investigatory modalities.

\section{Conflict of interest: None}

\section{REFERENCES}

1. Ohle R, O'Reilly F, O'Brien KK, Fahey T, Dimitrov BD. The Alvarado score for predicting acute appendicitis: a systematic review. BMC medicine. 2011;9:139. Crossref

2. Lintula H, Pesonen E, Kokki H, Vanamo K, Eskelinen M. A diagnostic score for children with suspected appendicitis. Langenbeck's archives of surgery. 2005;390:164-70. $\underline{\text { Crossref }}$

3. Fenyo G, Lindberg G, Blind P, Enochsson L, Oberg A. Diagnostic decision support in suspected acute appendicitis: validation of a simplified scoring system. The European journal of surgery = Acta chirurgica. 1997;163:831-8.

4. Singh A, Parihar US, Kumawat G, Samota R, Choudhary R. To Determine Validation of RIPASA Score in Diagnosis of Suspected Acute Appendicitis and Histopathological Correlation with Applicability to Indian Population: a Single Institute Study. The Indian journal of surgery. 2018;80:113-7. Crossref

5. Addiss DG, Shaffer N, Fowler BS, Tauxe RV. The epidemiology of appendicitis and appendectomy in the United States. American journal of epidemiology. 1990;132:910-25. Crossref

6. Chong CF, Adi MI, Thien A et al. Development of the RIPASA score: a new appendicitis scoring system for the diagnosis of acute appendicitis. Singapore medical journal. 2010;51:220-5. $\underline{\text { Crossref }}$
7. Chong CF, Thien A, Mackie AJ, et al. Comparison of RIPASA and Alvarado scores for the diagnosis of acute appendicitis. Singapore medical journal. 2011;52:340-5. $\underline{\text { Crossref }}$

8. Omundsen M, Dennett E. Delay to appendicectomy and associated morbidity: a retrospective review. ANZ journal of surgery. 2006;76:153-5. $\underline{\text { Crossref }}$

9. Kalan M, Talbot D, Cunliffe WJ, Rich AJ. Evaluation of the modified Alvarado score in the diagnosis of acute appendicitis: a prospective study. Annals of the Royal College of Surgeons of England. 1994;76:418-9. Crossref

10. N N, Mohammed A, Shanbhag V, Ashfaque K, S AP. A Comparative Study of RIPASA Score and ALVARADO Score in the Diagnosis of Acute Appendicitis. Journal of clinical and diagnostic research : JCDR. 2014;8:Nc03-5.

11. Butt MQ, Chatha SS, Ghumman AQ, Farooq M. RIPASA score: a new diagnostic score for diagnosis of acute appendicitis. Journal of the College of Physicians and Surgeons--Pakistan : JCPSP. 2014;24:894-7. Crossref

12. Alvarado A. A practical score for the early diagnosis of acute appendicitis. Annals of emergency medicine. 1986;15:557-64. $\underline{\text { Crossref }}$

13. Diaz-Barrientos CZ, Aquino-Gonzalez A, Heredia-Montano M, Navarro-Tovar F, Pineda-Espinosa MA, Espinosa de Santillana IA. The RIPASA score for the diagnosis of acute appendicitis: A comparison with the modified Alvarado score. Revista de gastroenterologia de Mexico. 2018;83:112-6. $\underline{\text { Crossref }}$

14. Xingye W, Yuqiang L, Rong W, Hongyu Z. Evaluation of Diagnostic Scores for Acute Appendicitis. Journal of the College of Physicians and Surgeons--Pakistan : JCPSP. 2018;28:110-4. Crossref

15. Rastovic P, Trninic Z, Galic G, Brekalo Z, Lesko J, Pavlovic M. Accuracy of Modified Alvarado Score, Eskelinen Score and Ohmann Score in Diagnosing Acute Appendicitis. Psychiatria Danubina. 2017;29:134-41. Crossref 